\title{
The Impact of Applied Agricultural Technologies on the Productivity of Agricultural Lands
}

\author{
K.J. Kachiashvili \\ Georgian Technical University, 77, st. M. Kostava, Tbilisi, 0175, Georgia, \\ I. Vekua Institute of Applied Mathematics of the Tbilisi State University, \\ 2, st. University, Tbilisi, 0179, Georgia \\ k.kachiashvili@gtu.edu.ge,kkachiashvili@gmail.com
}

\begin{abstract}
The profitability and efficiency of farming economies achieved by introduction of advanced agricultural methods during two years, in particular, the increase in the productivity of soil with the use of advanced manure, treated in biogas facilities, the increase in the productivity of degraded and low-productive agricultural lands (exchange of seeds, introduction of new cultures, drainage etc.) and soil erosion prevention techniques were investigated by application of the methods of mathematical statistics to the obtained results. High profitability, efficiency and economic justification of these methods are shown as a result of this investigation.
\end{abstract}

Keywords: Farming economy, Advanced agricultural methods, Soil productivity, Soil erosion prevention, Advanced manure, Environment pollution.

Abbreviations: IDA - International Development Association; GEF - World Fund of the Environment Protection; $N$-nitrogen; $P$ - mobile phosphorus; $K$ - exchangeable potassium; NPK-fertilizers.

With the support of the World Bank, the International Development Association (IDA) and the World Fund of the Environment Protection (GEF) the introduction-dissemination of advanced and profitable agricultural methods was realized in Georgia by the following means: 1) the introduction-dissemination of the achievements of scientific-technical progress and advanced technologies in farming economies; 2) the development of selected priority direction by the support of reforms of the research system, introduction-consultation and training; 3) the reduction of pollution of the environment and the Black Sea basin with agricultural cattle-breeding waste; with this purpose, the demonstrationintroduction of manure storehouses and biogas facilities of improved design; 4) realization of the monitoring of pollution levels of soil, groundwater and rivers.

We established the cause and effect dependences of the results of the subprojects realized in the scope of the Environmental Pollution Reduction Program (as was mentioned above and other similar subprojects, executed with coordination of the Georgian Agriculture Development Project Coordination Center and pollution levels of the environment and developed the recommendations for improving the practice of the use of less harmful technologies for the environment. The above was realized based on the processing of numerical data of the environment monitoring and other subprojects using the methods and means of mathematical statistics and data analysis.

\section{Materials \& Methods}

\subsection{Improvement of Fertility of Degraded and Low-Productive Agricultural Lands using Advanced Agricultural Technologies}

To achieve the aims listed in the introduction, the following subprojects were realized during two years within the scope of the projects: 1) The increase of the productivity of soils using advanced manure processed in biogas installations (totally 8 sub-projects; Priority I); 2) The increase of productivity of degraded and low-productive agricultural lands (exchange of seeds, introduction of new cultures, drainage etc.) (totally 17 sub-projects; Priority II); 3) Introduction of soil erosion prevention techniques (terracing, contour ploughing, expansion of buffer zones etc.) (totally 19 subprojects; 


\section{K.J. Kachiashvili}

Priority III). The duration of some subprojects was one year, and others - two years. The time interval of execution of each project was divided in tranches. Each tranche covered half a year.

The analysis of numerical information that reflected the results of subprojects was carried out by means of both modern methods and means of data processing and visualization of the obtained results. Among them there were used both a program package of processing of statistical information SPSS and an applied software package of processing of experimental information - SDpro created under the guidance of the author of the present work [1,2].

\subsection{Improvement of Soil Fertility and an Increase in Soil Productivity}

For establishment of the fact of the increase of soil fertility by means of measures taken in the subprojects, we realized the comparison of the spring and autumn contents of hydrolysis nitrogen $(\mathrm{N})$, mobile phosphorus $(\mathrm{P})$ and exchangeable potassium $(\mathrm{K})$ in the soils using two-year data. For this purpose, we used a non parametric method of comparison of two sets of observations, in particular, Wilcocson's test [3].

The content of the mentioned elements in the fields enclosed in one of subprojects of Priority I is given in Table 1. The results of processing are given in Appendix 1. From here, it is seen that the content of hydrolysed nitrogen in the spring of the first year exceeds its content in the autumn of the same year, and the content of nitrogen in the autumn of the first year is less than the spring content of the second year. The contents of the considered ingredient in soil in the springs of both years are similar, they are also similar in the autumns of these years, but the autumn contents are less than the spring contents. The contents of mobile phosphorus in the soils in the springs of the first and of the second years are similar and exceed the content in the autumn of the first year. The contents of exchangeable potassium in soil in the springs of the first and the second years and in the autumn of the first year are similar, but the second-year autumn content exceed the first-year autumn content. Finally, regarding to the soil fertility, we conclude that the contents of plant micronutrients in the fields enclosed by the subproject, changes as follows: the content of micronutrients in the springs of both years exceeded the autumn contents of appropriate years, but the content of mobile phosphorus and of exchangeable potassium in the autumn of the second year exceeded the autumn content of the first year, and the content of hydrolysed nitrogen in the autumn are similar. The above indicates on the sufficient efficiency of the measures realized by farmers.

The results of analysis of data of other subprojects of Priority I allow us to make the same conclusions in principle.

The content of nitrates in citrus, maize and potato crops grown on the basic and control fields are given in Table 1. From here it is seen that the contents of nitrates in the cultures grown on the basic fields are less than those in the same cultures grown on the control fields. In particular, in the citrus crop, this value is less by a factor of 1.26 , in the maize crop - by 1.5 , in the potato crop - by 1.09 on the average. In comparison with the previous year, the content of nitrates in the maize reduced 2.5 times on the average, in the potato - 1.09 times, and in citruses -1.24 times.

The average productivity of the maize in the first year of the project increased by $16 \%$ in comparison with the previous years by using advanced manure, and the average productivity of citruses - by $20 \%$ on the average. In the second year of the project, in comparison with the first year, the average productivity of the maize increased by $5-6 \%$, citruses - by $12-14 \%$ on the average and vegetables - by $20 \%$.

The amount of fertilizers used in the fields of 8 farmers, with total area 5.7 ha, reduced by 4.5 ton in a year.

\subsection{Correlation Analysis}

A complete correlation analysis allows us to establish whether there exist both linear and nonlinear ratios among the subsets of investigated parameters on the basis of observation results, noised (distorted) by random factors $[4,5]$ and the methods of regression analysis allow us to restore quantitatively these ratios at their existence $[6,7]$.

Based on the investigation of the dependences of the harvests of maize and tomato on the content of nutrients in the soil of the fields of one of subprojects of Priority I, we can infer the following. 
The Impact of Applied Agricultural Technologies on the Productivity of Agricultural Lands

Table 1. The results of projects of the increase of the productivity of degraded and low productive agricultural fields.

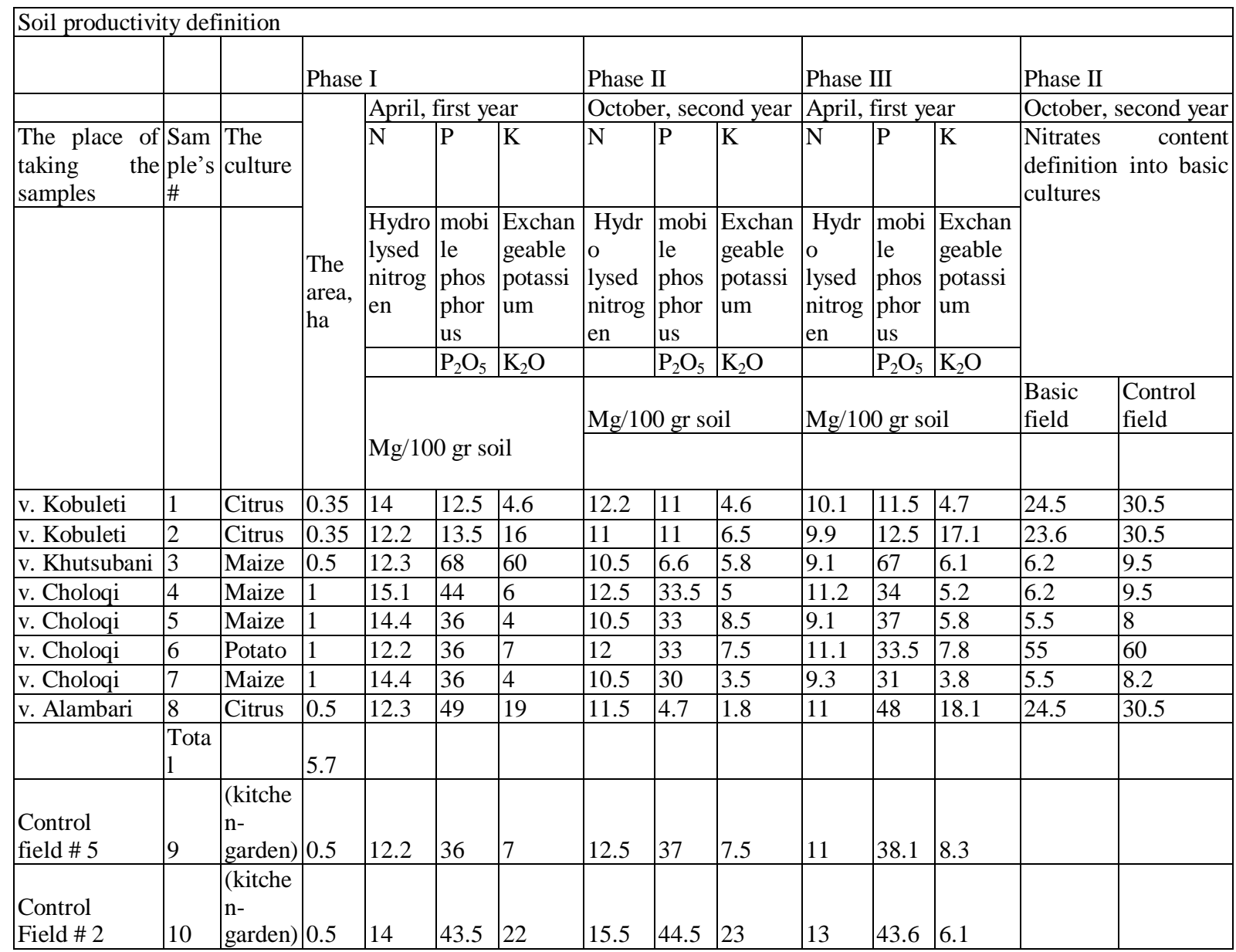

\begin{tabular}{|c|c|c|c|c|c|c|c|c|c|c|c|c|c|}
\hline \multirow{3}{*}{\multicolumn{2}{|c|}{$\begin{array}{l}\text { The quantity } \\
\text { of usec } \\
\text { advanced } \\
\text { manure }\end{array}$}} & \multirow{3}{*}{\multicolumn{3}{|c|}{$\begin{array}{l}\text { The quantity of the given manure that } \\
\text { was taken out of using with } \\
\text { comparison of the average amount of } \\
\text { the previose years } \\
\text { (t/year) }\end{array}$}} & \multicolumn{9}{|c|}{$\begin{array}{l}\text { Increasing of average productivity of two basic cultures by using } \\
\text { advanced manure, } \% \\
\text { (kg/year) }\end{array}$} \\
\hline & & & & & \multicolumn{5}{|c|}{ Farmer's fields } & \multicolumn{4}{|c|}{ Control fields } \\
\hline & & & & & \multirow[b]{2}{*}{$\begin{array}{l}\text { Average } \\
\text { productiv } \\
\text { ity of the } \\
\text { previous } \\
\text { years }\end{array}$} & \multirow[b]{2}{*}{$\begin{array}{l}\text { At } \\
\text { the enc } \\
\text { of the } \\
\text { Phase I }\end{array}$} & \multirow[b]{2}{*}{\begin{tabular}{l|l} 
& Incr \\
id & easi \\
ee & ng \\
I
\end{tabular}} & \multirow{3}{*}{$\begin{array}{l}\text { At } \\
\text { the end } \\
\text { of the } \\
\text { Phase II }\end{array}$} & \multirow[b]{2}{*}{$\begin{array}{l}\text { Incr } \\
\text { easi } \\
\text { ng } \\
\%\end{array}$} & \multirow[b]{2}{*}{$\begin{array}{l}\text { At } \\
\text { the end } \\
\text { of the } \\
\text { Phase I }\end{array}$} & \multirow[b]{2}{*}{$\begin{array}{l}\text { Incr } \\
\text { easi } \\
\text { ng } \\
\%\end{array}$} & \multirow[b]{2}{*}{$\begin{array}{l}\text { At } \\
\text { the end } \\
\text { of the } \\
\text { Phase II }\end{array}$} & \multirow[b]{2}{*}{$\begin{array}{l}\text { Incr } \\
\text { deasi } \\
\text { eas } \\
\text { II }\end{array}$} \\
\hline \begin{tabular}{|l|} 
Phas \\
e I \\
Brou \\
ght \\
manu \\
re
\end{tabular} & $\begin{array}{l}\text { Brought } \\
\text { manure }\end{array}$ & $\begin{array}{l}\text { Brought in } \\
\text { the } \\
\text { Previous } \\
\text { years }\end{array}$ & $\begin{array}{l}\text { Brought in } \\
\text { the } \\
\text { Current year }\end{array}$ & $\begin{array}{l}\text { Was taken } \\
\text { out } \\
\text { of using }\end{array}$ & & & & & & & & & \\
\hline $\mathrm{t}$. & t. & & & & $\mathrm{t} / \mathrm{he}$ & & & & & & & & \\
\hline 7.5 & & 0.3 & 0.05 & 0.25 & $18-20$ & - & & & & & & & \\
\hline 7.5 & & 0.3 & 0.05 & 0.25 & $18-20$ & 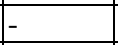 & & & & & & & \\
\hline \begin{tabular}{|l|}
17.5 \\
\end{tabular} & & 0.5 & 0.1 & 0.4 & $7-8$ & - & & 14 & & & & & \\
\hline 25 & & 1 & 0.2 & 0.8 & $7-8$ & - & & 15 & & & & & \\
\hline 25 & & 1 & 0.2 & 0.8 & $7-8$ & - & & 16.5 & & & & & \\
\hline 25 & & 1 & 0.2 & 0.8 & $10--12$ & - & & 17 & & & & & \\
\hline 25 & & 1 & 0.2 & 0.8 & $7-8$ & 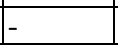 & & 16 & & & & & \\
\hline \begin{tabular}{|l|}
17.5 \\
\end{tabular} & & 0.5 & 0.1 & 0.4 & $18-20$ & - & & 11 & & & & & \\
\hline 150 & & 5.6 & 1.1 & 4.5 & & & & & & & & & \\
\hline & & & & & $7-8$ & & & & & & & 8 & \\
\hline & & & & & $18-20$ & & & & & & & - & \\
\hline
\end{tabular}




\section{K.J. Kachiashvili}

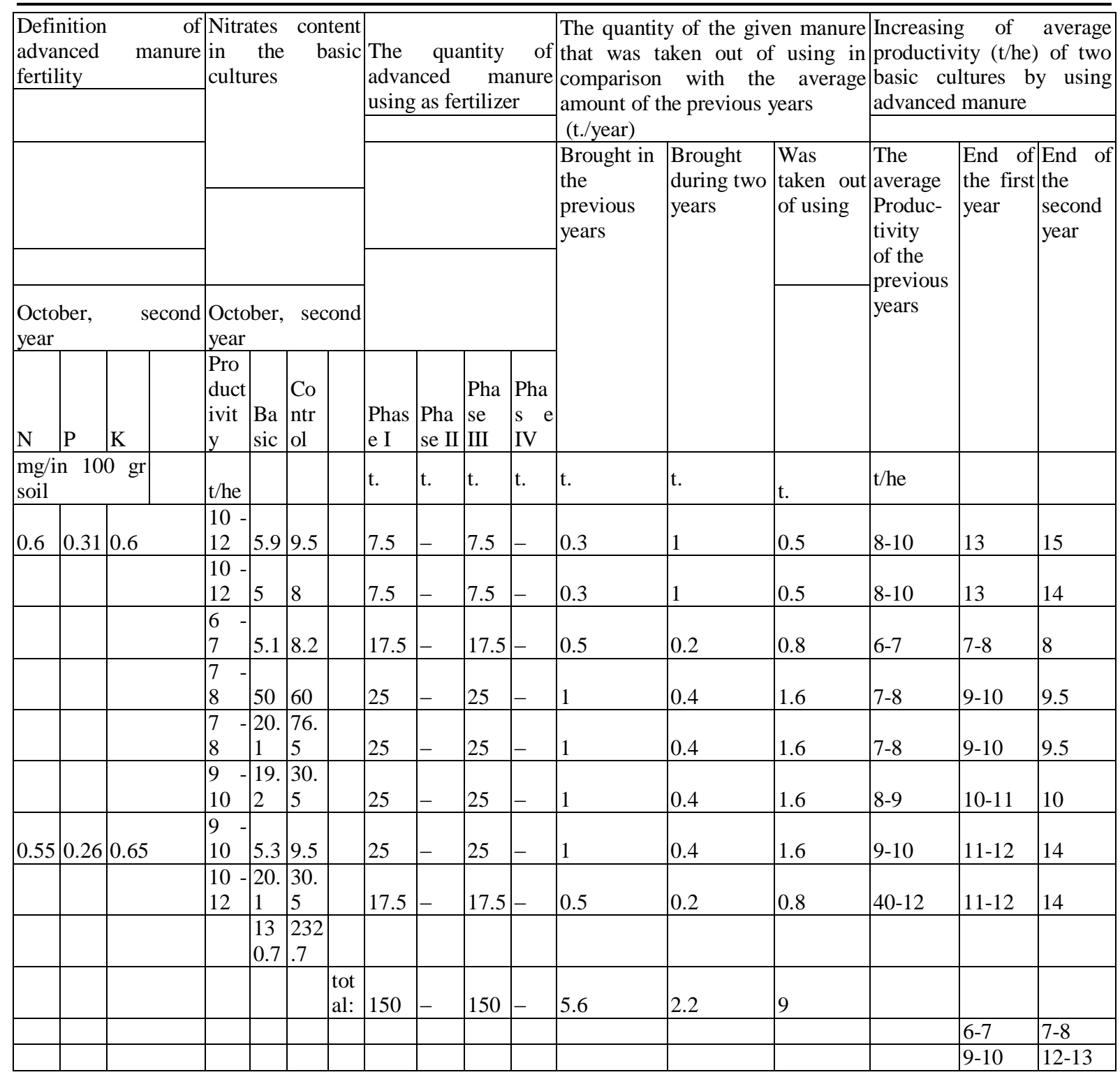

Positive correlations exist between the following parameters (see Table 2): 1,3; 1,4; 1,6; 2,5; 3,4; 3,6; 4,$6 ; 7,8$, and negative correlations exist between the following parameters: 1,$2 ; 1,5 ; 2,3 ; 2,4 ; 2,6 ; 3,5$; 4,$5 ; 5,6$. It means that the contents of hydrolysed nitrogen and exchangeable potassium in soil have similar tendencies to increase and decrease, i.e. the more hydrolysed nitrogen in the soil, the more exchangeable potassium there. The sizes of the maize and tomato crop yields vary similarly, i.e. they identically depend on the contents of hydrolysed nitrogen and exchangeable potassium in the soil. Between the contents of mobile phosphorus in the spring and autumn soils there is positive correlation, that means that the more is mobile phosphorus in the spring soil, the more is its amount in the autumn soil. The partial correlation coefficients (which describe joint behavior of two parameters holding other parameters fixed) exist between the maize and tomato crop yields and the contents of hydrolysed nitrogen and exchangeable potassium in the autumn soils. It means that the maize and tomato crop yields positively depend on the contents of hydrolysed nitrogen and exchangeable potassium in the autumn soils.

Table 2. The content of the nutrients in the soils of agricultural fields in the spring of the first year $(\mathrm{mg} / \mathrm{kg})$ and the size of the harvest.

\begin{tabular}{|c|c|c|c|c|c|c|c|}
\hline \multicolumn{3}{|c|}{$\begin{array}{l}\text { The content of the nutrients in the soils of } \\
\text { agriculture fields in spring of the first year }\end{array}$} & \multicolumn{3}{|c|}{$\begin{array}{l}\text { The content of the nutrients in the soils of } \\
\text { agriculture fields in autumn of the first year }\end{array}$} & \multicolumn{2}{|c|}{$\begin{array}{l}\text { The obtained } \\
\text { harvest on the } 1000 \\
\mathrm{~m}^{2}\end{array}$} \\
\hline \multirow[t]{2}{*}{$\begin{array}{l}\text { Hydrolysed } \\
\text { nitrogen }\end{array}$} & \multirow{2}{*}{$\begin{array}{l}\text { Mobile } \\
\text { phosphorus } \\
\mathrm{P}_{2} \mathrm{O}_{5}\end{array}$} & \multirow[t]{2}{*}{$\begin{array}{l}\text { Exchangeable } \\
\text { potassium, } \mathrm{K}_{2} \mathrm{O}\end{array}$} & \multirow[t]{2}{*}{$\begin{array}{l}\text { Hydrolysed } \\
\text { nitrogen }\end{array}$} & \multirow{2}{*}{$\begin{array}{l}\text { Mobile } \\
\text { phosphorus, } \\
\mathrm{P}_{2} \mathrm{O}_{5}\end{array}$} & \multirow[t]{2}{*}{$\begin{array}{l}\text { Exchangeable } \\
\text { potassium, } \mathrm{K}_{2} \mathrm{O}\end{array}$} & & \\
\hline & & & & & & $\begin{array}{l}\text { Maize, } \\
\mathrm{kg}\end{array}$ & $\begin{array}{l}\text { Tomato, } \\
\mathrm{kg}\end{array}$ \\
\hline 1 & 2 & 3 & 4 & 5 & 6 & 7 & 8 \\
\hline
\end{tabular}


The Impact of Applied Agricultural Technologies on the Productivity of Agricultural Lands

\begin{tabular}{|l|l|l|l|l|l|l|l|}
\hline \hline 56 & 118 & 58 & 56 & 139 & 61 & 620 & 1600 \\
\hline 60 & 125 & 56 & 61 & 138 & 59 & 600 & 1500 \\
\hline 58 & 130 & 50 & 57 & 137 & 51 & 580 & 1550 \\
\hline 54 & 126 & 52 & 61 & 134 & 53 & 600 & 1520 \\
\hline 57 & 122 & 54 & 57 & 128 & 55 & 400 & 1200 \\
\hline 76 & 25 & 105 & 79 & 27 & 107 & 600 & 1450 \\
\hline 72 & 20 & 110 & 73 & 21 & 119 & 560 & 1400 \\
\hline 69 & 26 & 108 & 68 & 27 & 109 & 520 & 1480 \\
\hline 70 & 22 & 100 & 73 & 25 & 109 & 580 & 1420 \\
\hline 73 & 24 & 108 & 73 & 25 & 110 & 380 & 1100 \\
\hline
\end{tabular}

We investigated the dependences of the contents of the nitrates in the maize, cucumber and tomato crops on the contents of nutrients (NPK) in the soil in the farming fields enclosed by the second subproject of Priority I. Based on the obtained results, we can conclude that (see Appendix 2): 1) There is a positive correlation between the averaged contents of nitrates in the maize, cucumber and tomato crops, i.e. the more is the content of nitrates in one of these cultures, the more is its content in others and vice versa. 2) There is a positive correlation between the contents of hydrolysed nitrogen in the soils in the spring and the autumn; the same takes place for exchangeable potassium. It means that the more are the contents of these substances in the soils in the spring, the more are their contents in the soils in the autumns. 3) Between the contents of hydrolysed nitrogen in the spring soils and the contents of mobile phosphorus in the autumn, as well as between the contents of mobile phosphorus in the spring soils and of hydrolysed nitrogen in the autumn soils, there are negative correlations, i.e. when one of them increases, the other decreases and vice versa.

The results of analysis of the data, obtained in the farming economies enclosed by other subprojects of Priority I, allowed us to make the same conclusions.

\subsection{Regression Analysis}

As the realized regression analysis showed the tomato crop yield is inversely proportional to the content of hydrolysed nitrogen in the autumn soil. This dependence is quite well described by a geometrical dependence with a free component $y=a+b \cdot x^{c} \quad$ (see Fig. 1). The relative value of the difference between the restored dependence and the subproject data is no more than 9\% (see Appendix 3). There is also an inverse proportional dependence between the maize crop yield and the contents of hydrolyzed nitrogen in the autumn soils, which is described by a geometrical dependence with a free member as well (see Fig. 2). The relative value of the difference between the restored dependence and the data of the subproject is no more than $15 \%$ (see Appendix 4). Finally, we established that the more is the content of hydrolyzed nitrogen in the autumn soils, the less are the tomato and maize crop yields.

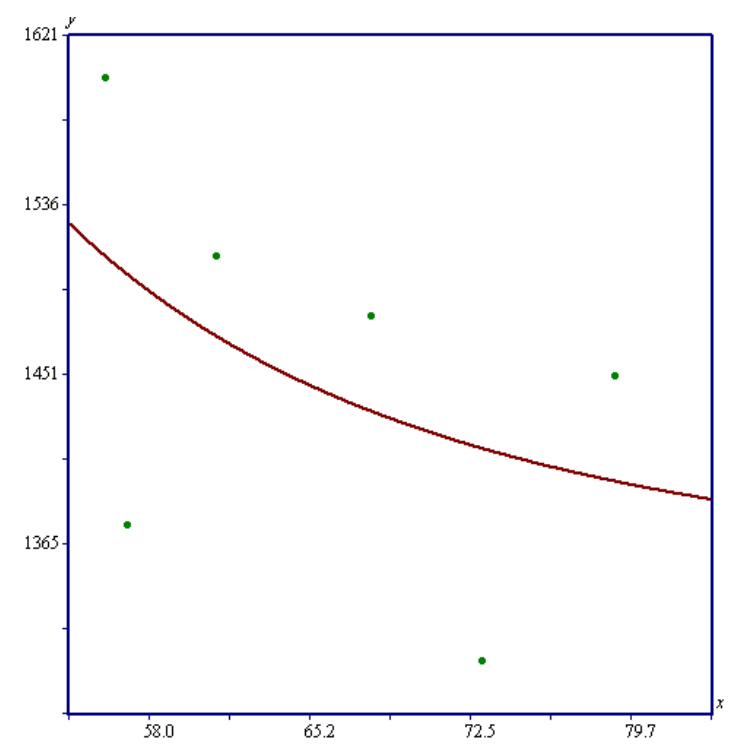

Fig. 1. The dependence of the harvest size of tomato from the content of the hydrolyzed nitrogen in the soil.

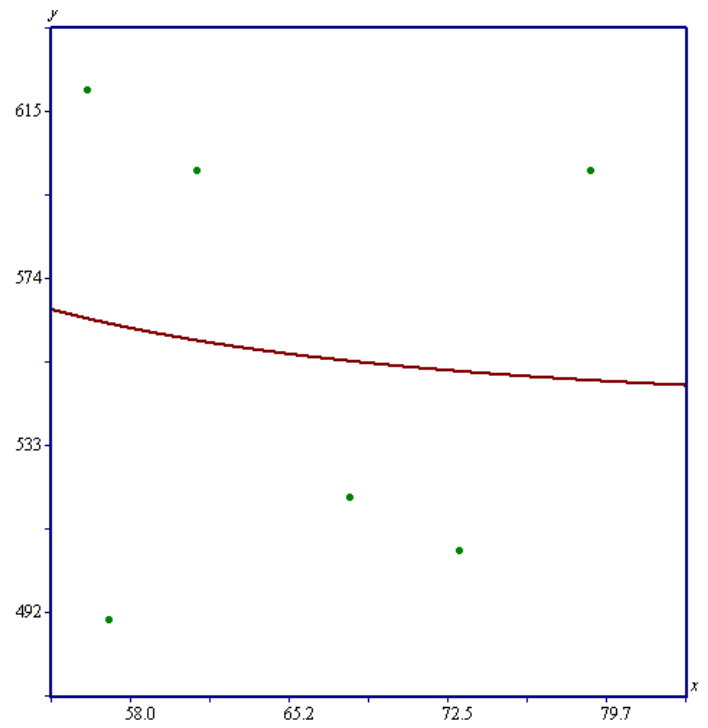

Fig. 2. The dependence of the harvest size of maize from the content of the hydrolyzed nitrogen in the soil. 


\section{RESULTS \& DiSCUSSION}

\subsection{The Increase of Agricultural Productivity}

Based on the data on farming fields covered by one of the subprojects united in Priority I, in comparison with the previous years, the average productivity of maize increased by $92 \%$ in the first year of the project by applying advanced manure; the average productivity of potato - by $54.5 \%$. By the data of the second subprojects, in comparison with the previous years, the productivity in the first year increased: maize - by $77 \%$, tomato - by $100 \%$; in comparison with control fields: maize - by $87 \%$, tomato - by $95 \%$. By the data of another subproject, the productivity in the first year increased in comparison with control fields: mandarin - by $20-25 \%$, kiwi fruit - by $20 \%$. The average amounts of fertilizers (NPK) withdrawn from the use per hectare are: ammonium nitrate $-350 \mathrm{~kg}$, potassium salt $-178 \mathrm{~kg}$ and phosphorus $-250 \mathrm{~kg}$.

Based on the above-mentioned and similar results of other subprojects of tPriority I, it is possible to make the following conclusions. In the basic fields covered by the project, the average productivity increased in the first year in comparison with control fields: maize - by $20-30 \%$, citruses - by $20-25 \%$ and potato - by $23-25 \%$. In some subprojects the increase of productivity of maize and potato in comparison with control fields reached $87 \%$ and $95 \%$, respectively. The average amount of fertilizers (NPK) withdrawn from the use per hectare makes up 300-350 kg.

Based on similar investigations, we can make the following conclusions. In the first year the average productivity in the basic fields enclosed by subprojects incorporated in the direction "Increase of productivity of degraded and low-productive agricultural fields (exchange of seeds, introduction of new cultures, drainage) (Priority II) in comparison with control fields increased: maize - by 30-40\%, soya - by $20-32 \%$. The increase of the productivity of maize in comparison with control fields in some subprojects reached 55\%. The average amount of fertilizers (NPK) withdrawn from the use per hectare made up 300-375 kg.

\subsection{Reduction of Soil Erosion}

As was mentioned above, 19 subprojects were incorporated in the direction "Introduction of soil erosion prevention techniques (terracing, contour ploughing, expansion of buffer zones etc.)" (Priority III). A brief description of the results obtained in these subprojects is presented below.

The agricultural fields of four farmers with total area 2.95 ha were covered by one of the subprojects of Priority III. The initial value of the erosion indicator of the fields was 45-70\%. As a result of realized measures and introduced fertilizers (in average $33.9 \mathrm{t}$. advanced manure and $1.36 \mathrm{t}$. peat per 1 ha), the soil erosion was reduced by $25-30 \%$ and the average productivity of two basic cultures, nuts and maize, increased by $20-25 \%$ and $20-30 \%$, respectively.

According to the data of the second subproject of Priority III, by the realized measures, the average productivity of soya in the first year increased by $56 \%$ in comparison with control fields. The erosion indicator was reduced in average by $20 \%$. By the data of other subproject of Priority III, by the realized measures, the erosion indicator was reduced in average by $21 \%$; the average productivity was increased in the first year in comparison with control fields: maize - by $20-30 \%$, soya - by $50 \%$; walnut - by 20-25\%. Similar results were obtained in other subprojects of the considered priority.

The following conclusion follows from the above. The average productivity in the basic fields enclosed in Priority III in the first year increased in comparison with control fields: maize - by 20$30 \%$, nut - by $20-25 \%$ and soya - by $50 \%$. The erosion indicator was reduced in average by $70-75 \%$.

\section{Conclusion}

As a result of above-presented investigations, we conclude that the application of the methods increasing the productivity of soils using advanced manure processed in biogas installations and increasing the productivity of degraded and low-productive agricultural fields (exchange of seeds, introduction of new cultures, drainage), and the introduction of soil erosion prevention techniques (terracing, contour ploughing, expansion of buffer zones etc.) realized in farming fields give high profitable, effective and economically justified results.

\section{REFERENCES}

[1] A. Bühl and P. Zöfel, SPSS Version 10. Einführung in die moderne datenanalyse unter Windows, Munchen: Pearson Education Deuttschland GmbH, 2001. 
[2] Kachiashvili K.J. and Melikdzhanian D.I., SDpro - The Software Package for Statistical Processing of Experimental Information, Int. J. Information Technology \& Decision Making (IJITDM), 9(1), 115-144, (2010).

[3] M. Hollander and D.A. Wolfe, Nonparametric Statistical Methods, New York: John Wiley and Sons, 1973.

[4] A. Stuart, J.K. Ord and S. Arnols, Kendall's Advanced Theory of Statistics. Classical Inference and the Linear Model, 6st ed. New York: Oxford University Press Inc., 1999.

[5] Kachiashvili K.J. and Nakani D.V., Research of influence of traditional and modern agricultural methods and technology on a level of pollution of the rivers both agricultural areas, Conference Proceeding, IEEE International Engineering Management Conference, Innovation and Entrepreneurship for Sustainable Development, 3(3), Singapore, pp1314-1318 (2004).

[6] D.A. Freedman, Statistical Models: Theory and Practice, U.K.: Cambridge University Press, 2005.

[7] Kachiashvili K.J. and Nakani D.V., Research of dependences of agricultural cultures harvests and their ecological quality from contents in soil of different forms of nitrates, phosphates and potassium. Conference Proceding, 2nd International Congress "Sustainable Management in Action", University of Geneva: UNIMAIL, pp 103-107, (2005).

Appendix 1. Results of statistical processing of the data on the technologies of increasing the soil productivity with the use of advanced manure (Priority I)

The comparison of the soil productivity

Hydrolyzed nitrogen $-\mathrm{N}$

1) First sample size: $\quad N 1=10$

Second sample size: $\quad N 2=10$

Significance level: $\quad \alpha=0.0500$

a) Statistics: $\quad W=76.5000$

Boundary value of significance level: $\quad \beta=0.01440$

Hypothesis-acceptance region: [83.0000, $+\Gamma]$

Result:

The sample 1(April, first year) surpasses of the sample 2 (October, first year)

b) Statistics: $\quad W=76.5000$

Boundary value of significance level: $\quad \beta=0.02881$

Hypothesis-acceptance region: [79.0000, 131.000]

Result:

The samples are statistically dissimilar (April, first year and October, first year)

2) First sample size: $N 1=10$

Second sample size: $\quad N 2=10$

Significance level: $\quad \alpha=0.0500$

Alternatives: One tailed (right)

a) Statistics: $\quad W=131.000$

Boundary value of significance level: $\quad \beta=0.02621$

Hypothesis-acceptance region: [ $-\Gamma, 127.000]$

Result:

The sample 2 (October, first year) surpasses of the sample 1(April, second year)

b) Statistics: $\quad W=131.000$ 


\section{K.J. Kachiashvili}

Boundary value of significance level: $\quad \beta=0.05243$

Hypothesis-acceptance region: [79.0000, 131.000]

Result:

The samples are statistically dissimilar (October, first year and April, second year)

Mobile phosphorus - $\mathrm{P}_{2} \mathrm{O}_{5}$

1) First sample size: $N 1=10$

Second sample size: $\quad N 2=10$

Significance level: $\quad \alpha=0.0500$

Alternatives: One tailed (left)

Statistics: $\quad W=77.0000$

Boundary value of significance level: $\quad \beta=0.01440$

Hypothesis-acceptance region: $[83.0000,+\lceil]$

Result:

The sample 1 (April, first year) surpasses of the sample 2 (October, first year)

2) First sample size: $N 1=10$

Second sample size: $\quad N 2=10$

Significance level: $\quad \alpha=0.0500$

Alternatives: One tailed (left)

Statistics: $\quad W=80.0000$

Boundary value of significance level: $\quad \beta=0.02621$

Hypothesis-acceptance region: [83.0000, $+\Gamma]$

Result:

The sample 1 (April, second year) surpasses of the sample 2(October, first year)

3) First sample size: $N 1=10$

Second sample size: $\quad N 2=10$

Significance level: $\quad \alpha=0.0500$

Alternatives: Two tailed

Statistics: $\quad W=112.500$

Boundary value of significance level: $\quad \beta=0.57874$

Hypothesis-acceptance region: [79.0000, 131.000]

Result:

The samples (April, first year and April, second year) are statistically similar

Exchangeable potassium $-\mathrm{K}$

1) First sample size: $N 1=10$

Second sample size: $\quad N 2=10$

Significance level: $\quad \alpha=0.0500$

Alternatives: Two tailed

Statistics: $\quad W=94.5000$

Boundary value of significance level: $\quad \beta=0.43587$ 
Hypothesis-acceptance region: [79.0000, 131.000]

Result:

The samples (April, first year and October, first year) are statistically similar

2) First sample size: $N 1=10$

Second sample size: $\quad N 2=10$

Significance level: $\quad \alpha=0.0500$

Alternatives: Two tailed

Statistics: $\quad W=97.5000$

Boundary value of significance level: $\quad \beta=0.57874$

Hypothesis-acceptance region: [79.0000, 131.000]

Result:

The samples (April, second year and October, first year) are statistically similar

3) First sample size: $N 1=10$

Second sample size: $\quad N 2=10$

Significance level: $\quad \alpha=0.0500$

Alternatives: Two tailed

Statistics: $\quad W=112.000$

Boundary value of significance level: $\quad \beta=0.63053$

Hypothesis-acceptance region: [79.0000, 131.000]

Result:

The samples (April, first year and April, second year) are statistically similar

4) First sample size: $N 1=10$

Second sample size: $\quad N 2=10$

Significance level: $\quad \alpha=0.0500$

Alternatives: One tailed (right)

Statistics: $\quad W=145.000$

Boundary value of significance level: $\quad \beta=0.00075$

Hypothesis-acceptance region: [ - Г, 127.000]

Result:

The sample 2 (October, second year) surpasses of the sample 1 (October, first year)

Appendix 2. The dependence of the content of nitrates in maize, cucumber and tomato crops on the content of nutrients in the soil.

Complete correlation analysis by SDpro

\section{CORRELATION FACTOR SIGNIFICANCE}

INITIAL DATA

Dimensionality of the random process: $\mathrm{m}=9$

The number of measured values: $\quad \mathrm{N}=8$

Significance level: $\quad \mathrm{A}=0.050$

Connectivity depth: $\quad \mathrm{K}=0$ 
CALCULATION RESULT

TABLE OF SELECTED CORRELATION FACTORS

Correlation factors: $\mathrm{O}_{-}\{\mathrm{j}, \mathrm{k}\}(\mathrm{L})$

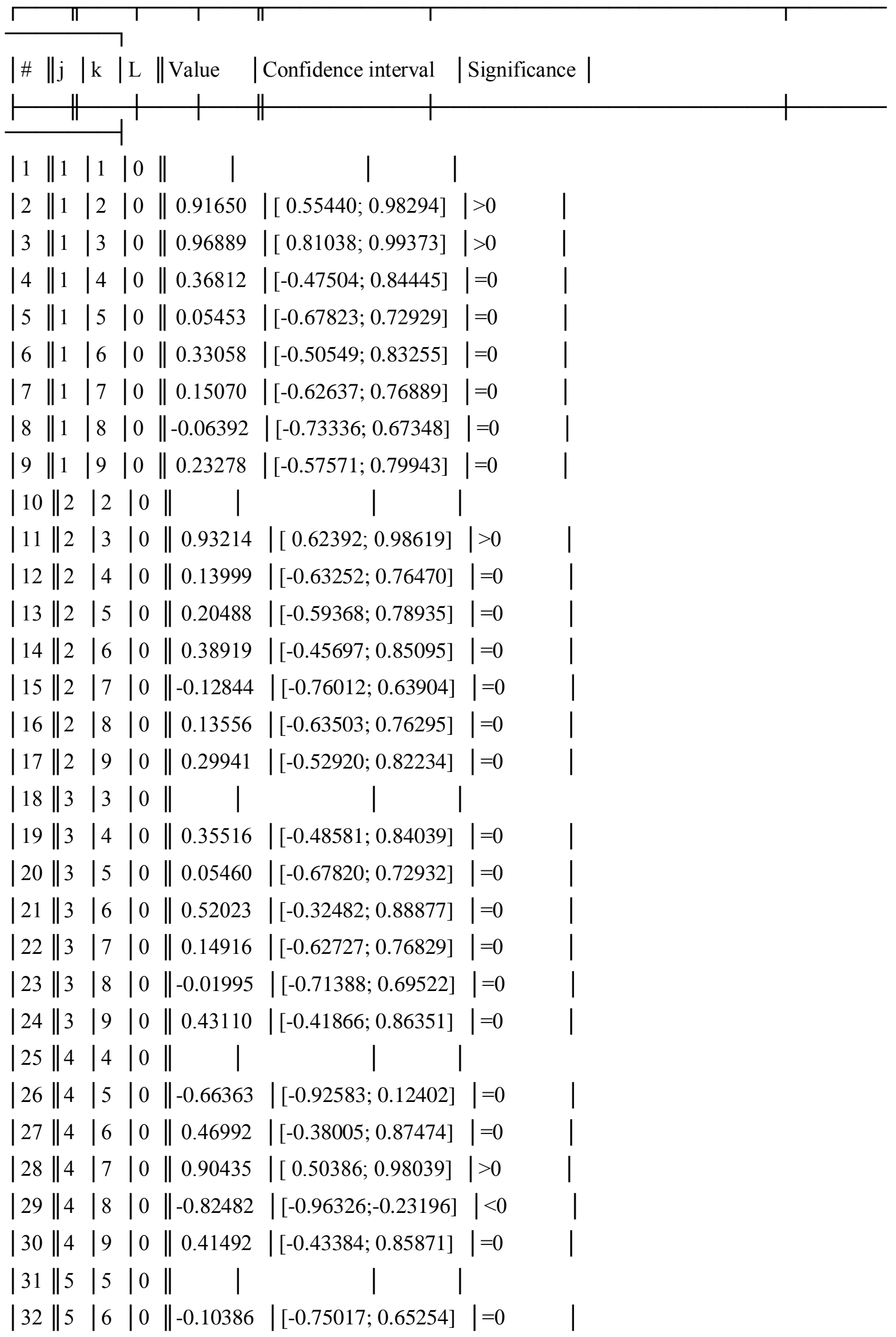




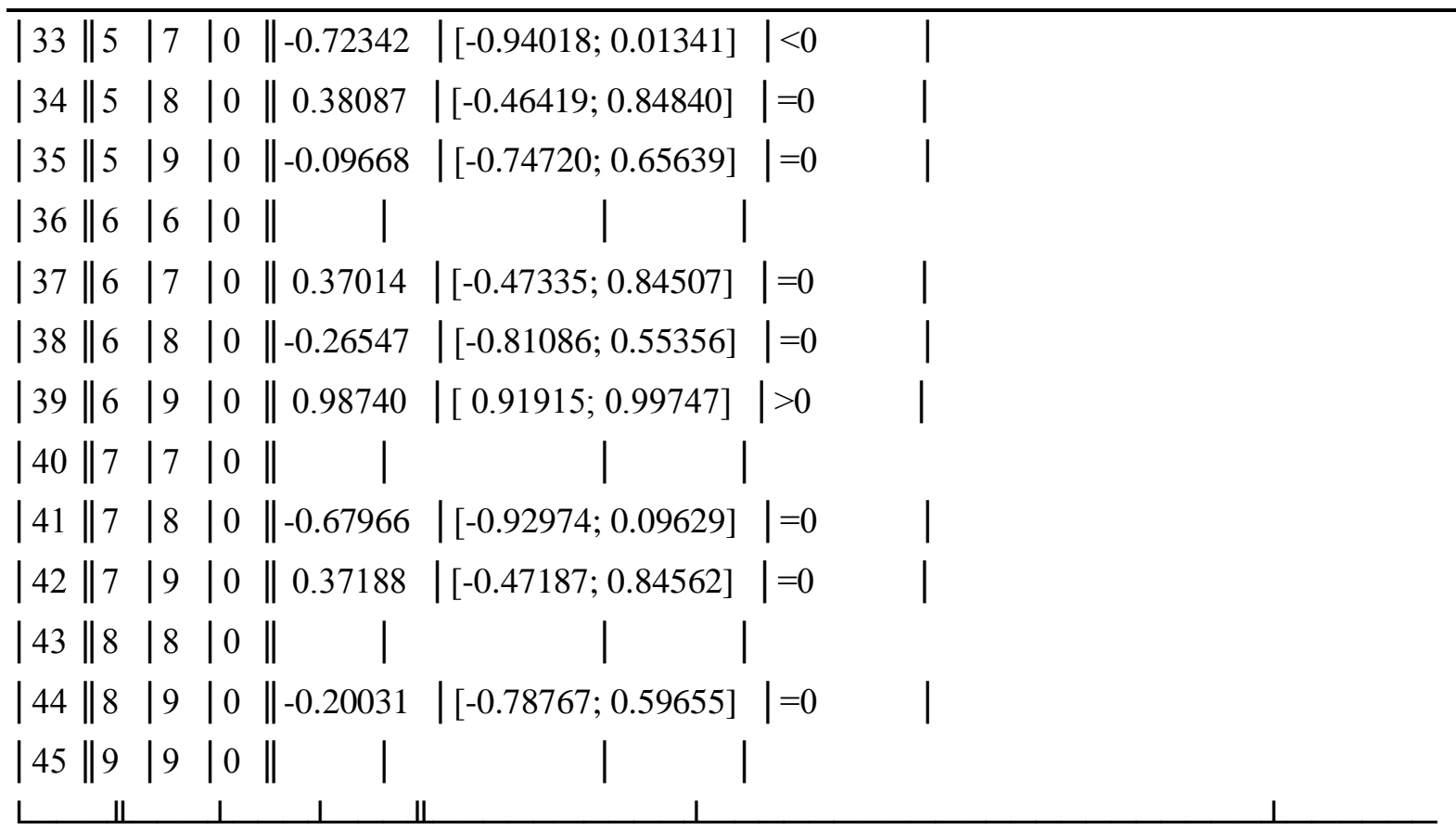

Appendix 3. The results of restoration of the dependence of the tomato crop yield on the content of hydrolyzed nitrogen in the soil.

\section{RESTORATION OF FUNCTIONAL DEPENDENCES}

INITIAL DATA AND SAMPLE PARAMETERS

The number of points: $\mathrm{N}=6$

Minimum argument value: $\mathrm{x}_{-}\{\min \}=56.000000$

Maximum argument value: $x_{-}\{\max \}=79.000000$

Minimum function value: $y_{-}\{\min \}=1306.7000$

Maximum function value: $y_{-}\{\max \}=1600.0000$

Type of dependence:

\section{GEOMETRICAL WITH A FREE TERM}

Explicit form of the function:

$$
y=a+b \cdot x^{c},
$$

The number of steps for searching of parameters: $\mathrm{I}=0$

\section{PARAMETERS OF APPROXIMATION}

Values of parameters:

$$
\begin{gathered}
\mathrm{a}=1336.4550 ; \mathrm{b}=4.29020 \mathrm{e} 7 ; \\
\mathrm{c}=-3.0850061
\end{gathered}
$$

Intervals of search of parameters:

$$
\text { с м[-4.5772374, 4.5772374] }
$$

\section{DEVIATIONS}

The standard deviation: $\quad \Pi=102.5158$

Sum of error squares: $\quad S=42037.94$

Maximum absolute deviation: \max Цy_j $=125.7380$

Maximum relative deviation: $\ \max Ц \mathrm{y}_{\mathrm{j}} \mathrm{j} / \mathrm{y} \_\mathrm{j}=0.091446$ 
TABLE OF DEVIATIONS

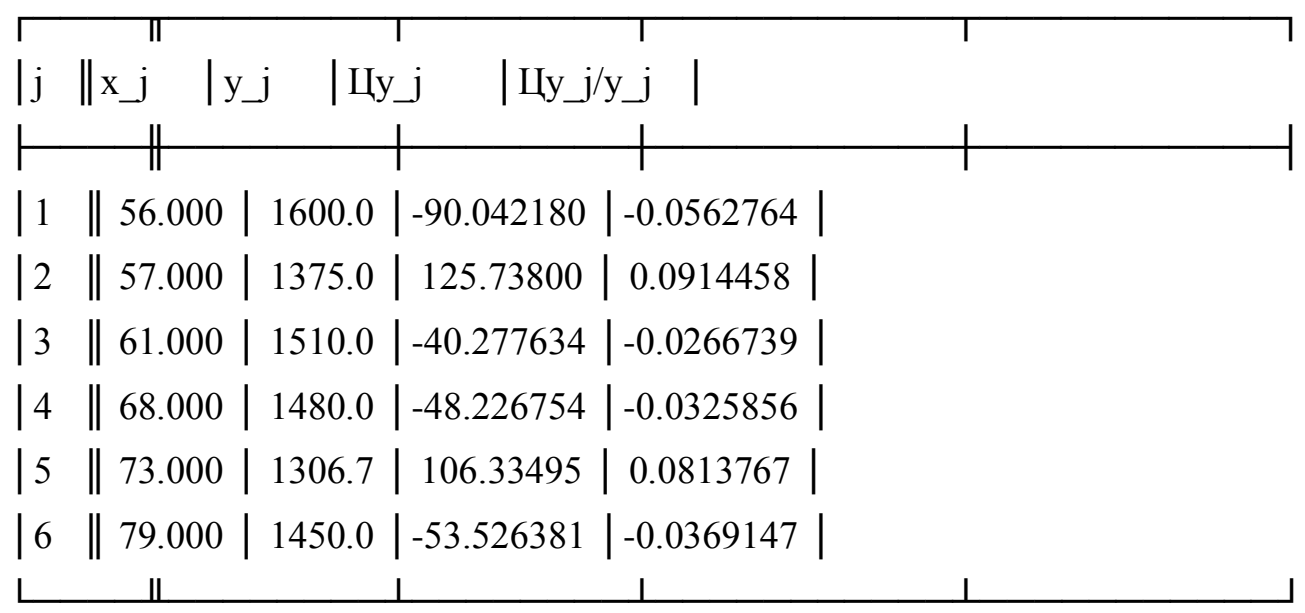

Appendix 4. The results of restoration of the dependence of the maize crop yield on the content of hydrolyzed nitrogen in the soil.

\section{RESTORATION OF FUNCTIONAL DEPENDENCES}

INITIAL DATA AND SAMPLE PARAMETERS

The number of points: $\mathrm{N}=6$

Minimum argument value: $\mathrm{x}_{-}\{\min \}=56.000000$

Maximum argument value: $x_{-}\{\max \}=79.000000$

Minimum function value: $y_{-}\{\min \}=490.00000$

Maximum function value: $y_{-}\{\max \}=620.00000$

Type of dependence:

\section{GEOMETRICAL WITH A FREE TERM}

Explicit form of the function:

$$
y=a+b \cdot x^{c},
$$

The number of steps for searching of parameters: $I=0$

\section{PARAMETERS OF APPROXIMATION}

Values of parameters:

$$
\begin{gathered}
\mathrm{a}=540.44459 ; \mathrm{b}=5738764.4 ; \\
\mathrm{c}=-3.0850061
\end{gathered}
$$

Intervals of search of parameters:

$$
\text { с м[-4.5772374, 4.5772374] }
$$

\section{DEVIATIONS}

The standard deviation: $\quad \Pi=62.95396$

Sum of error squares: $\quad S=15852.81$

Maximum absolute deviation: \max Цу_j $=72.41983$

Maximum relative deviation: $\ \max Ц \mathrm{y}_{\mathrm{j}} \mathrm{j} / \mathrm{y} \_\mathrm{j}=0.147796$

TABLE OF DEVIATIONS

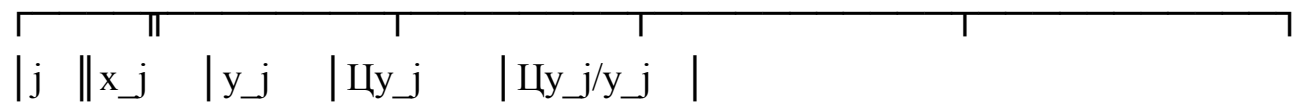


The Impact of Applied Agricultural Technologies on the Productivity of Agricultural Lands

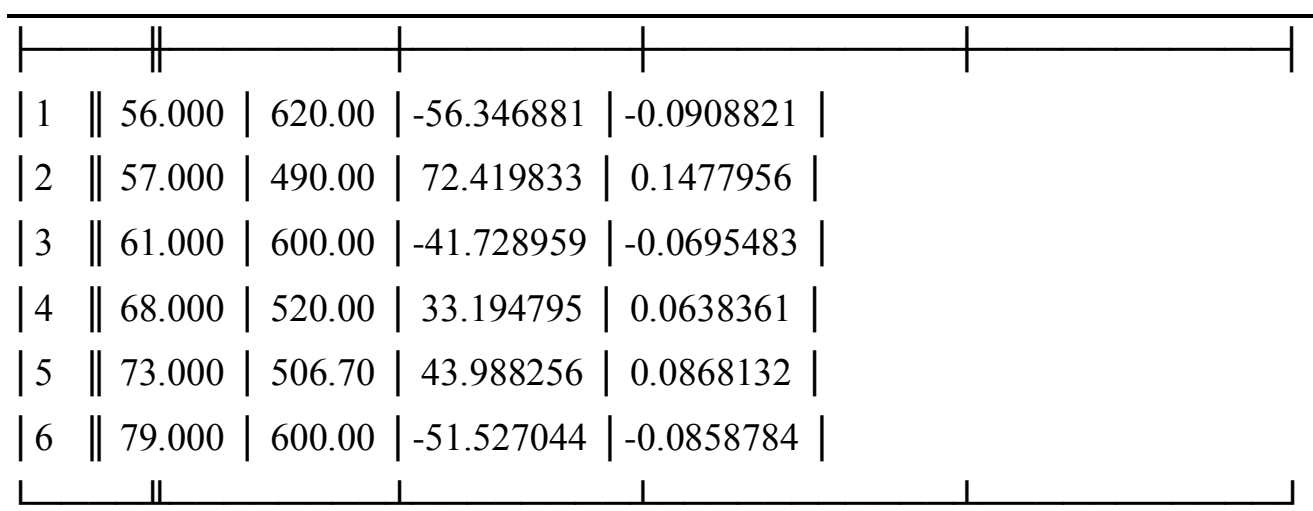

